\title{
PENGARUH ARUS KAS OPERASI, LABA BERSIH, UKURAN PERUSAHAAN DAN PRICE BOOK VALUE TERHADAP HARGA SAHAM
}

\author{
Heriston Sianturi ${ }^{1}$, Anji Angger Bimo Setyo Wibowo ${ }^{2}$ \\ ${ }^{1}$ Universitas Satya Negara Indonesia \\ e-mail: ${ }^{1}$ heriston@usni.ac.id, ${ }^{2}$ anjibimo@gmail.com

\begin{tabular}{ccc} 
Diterima & Direvisi & Disetujui \\
$31-01-2022$ & $17-02-2022$ & $23-02-2022$ \\
\hline
\end{tabular}

\begin{abstract}
Abstrak - Penelitian ini bertujuan untuk memberikan bukti mengenai pengaruh arus kas operasi, laba bersih, ukuran perusahaan dan nilai buku saham terhadap harga saham. Variabel yang diteliti yaitu arus kas operasi, laba bersih, ukuran perusahaan dan nilai buku saham sebagai variabel independen serta harga saham sebagai variabel dependen. Sampel yang digunakan dalam penelitian ini adalah perusahaan indeks LQ45 yang terdaftar di BEI yang aktif diperdagangkan dari tahun 2016 sampai dengan 2019. Metode pengambilan sampel yang digunakan adalah purposive sampling dimana pengambilan sampel dilakukan berdasarkan syarat-syarat tertentu. Metode statistik yang digunakan dalam penelitian ini adalah metode regresi linier berganda. Hasil penelitian menunjukkan bahwa variabel arus kas operasi, laba bersih, ukuran perusahaan dan nilai buku saham secara simultan berpengaruh signifikan terhadap harga saham. Sedangkan secara parsial variabel arus kas operasi, laba bersih dan ukuran perusahaan berpengaruh signifikan terhadap harga saham.

Kata Kunci : Arus Kas Operasi; Harga Saham; Laba Bersih; Nilai Buku Saham; Ukuran

Perusahaan
\end{abstract}

Abstract - This research was a puspose to provide empirical eviden about operating cash flow, net income, SIZE firm and stock market value that effect to the stock price. The ratio in this research were AKO, Earning After Tax (EAT), SIZE (Ln Tottal Asset), and Price to Book Value $(P B V)$ as independent variables and stock price as dependent variable. The samples of this research are LQ45 Index company that being active are traded and listed in BEI 2016-2019. Moreover, it is chosen by purposive sampling whereas it is based on some criteria. The statistic method used to test on the research hypothesis is multiple liniear regression. The result show that AKO, Earning After Tax (EAT), SIZE (Ln Tottal Asset), and Price to Book Value (PBV) simultaneously are significant in prediction the stock price which will be traded. This research also indicate that AKO, Earning After Tax (EAT), and SIZE (Ln Tottal Asset) partial are significant in prediction the stock price which will be traded.

Keywords : Operating Cash Flow, Net Income, SIZE Firm, Price Book Value, and Stock Price.

\section{PENDAHULUAN}

Seiring dengan pesatnya perkembangan globalisasi bisnis di Indonesia, tingkat persaingan perusahaan untuk mendapat keuntungan (profit) juga semakin ketat. Untuk bisa bersaing sekaligus memenangkan persaingan tersebut, banyak tantangan yang harus dihadapi oleh perusahaan. Salah satu diantaranya adalah tantangan yg wajib dihadapi sang perusahaan. Salah satu antara lain merupakan terkait menggunakan kebutuhan akan pendanaan yang 
dibutuhkan seperti tambahan setoran modal saham lewat pasar modal untuk menciptakan struktur permodalan yang kuat.

Disisi lain Sarana yang dapat digunakan oleh investor untuk investasi adalah dengan menanamkan modalnya dalam bentuk saham adalah pasar modal. Perusahaan dapat memperoleh pendanaan melalui pasar modal dengan melakukan penawaran sebagian saham perusahaan kepada publik sekaligus mencatatkan sahamnya di Bursa Efek Indonesia (BEI) atau yang biasa disebut go public. Perusahaan-perusahaan yang sudah go public mendapatkan banyak manfaat ketika mendaftarkan perusahaannya melalui pencatatan perdana saham (Initial Public Offering/IPO), salah satunya yaitu memperoleh sumber pendanaan baru.

Harga saham adalah harga saham dipasar bursa yang secara eksklusif yg dipengaruhi sang pelaku pasar (Jogiyanto, 2017:208). Salah satu indikator yg sangat krusial yang wajib sebagai perhatian investor dalam melakukan investasi merupakan harga pasar saham. Kondisi harga saham di bursa sangat penting dalam mengambil keputusan investor dalam membeli atau menjual saham yg dimilikinya. Harga saham dapat mencerminkan keberhasilan perusahaan atas pengelolaan operasionalnya. Keuntungan atau profit yang dihasilkan oleh perusahaan akan memberikan kepuasan kepada para investor terhadap kinerja perusahaan tersebut. Investor dapat menggunakan laporan keuangan yang dipublikasikan oleh perusahaan tiap periode untuk melihat tingkat keberhasilannya dalam menghasilkan keuntungan.

Objek penelitian yang dipilih adalah indeks LQ45 yang terdiri dari 45 emiten dengan likuiditas tinggi, yang diseleksi melalui beberapa kriteria pemilihan (Sri Hermuningsih, 2019:141), dengan alas an karena saham-saham indeks LQ45 merupakan saham-saham yang paling banyak diminati investor dipasar modal Indonesia, memiliki tingkat likuiditas tinggi, nilai kapitalisasi pasar (volume transaksi) yang tinggi, dan dijadikan patokan naik turunnya harga saham di Bursa Efek Indonesia. Harga saham yang fluktuatif dipasar modal menjadi sebuah fenomena yang menarik untuk dipelajari, khususnya saham perusahaan indeks LQ45 yang terdaftar di BEI periode 2016-2019 seperti terlihat pada Tabel 1 berikut ini :

Tabel 1 : Harga Saham Perusahaan Indeks LQ45 Periode 2016-2019

\begin{tabular}{|c|l|c|r|r|r|r|}
\hline \multirow{2}{*}{ No } & \multirow{2}{*}{ Perusahaan } & \multirow{2}{*}{ Kode } & \multicolumn{4}{|c|}{ Tahun } \\
\cline { 4 - 7 } & & & Tahun 2016 & Tahun 2017 & Tahun 2018 & Tahun 2019 \\
\hline 1 & PT Aneka Tambang, Tbk & ANTM & 895 & 625 & 765 & 835 \\
\hline 2 & PT Astra International, Tbk & ASII & 8.275 & 8.300 & 8.225 & 6.850 \\
\hline 3 & PT Bank Central Asia, Tbk & BBCA & 15.500 & 21.900 & 26.000 & 33.525 \\
\hline 4 & PT Bank Rakyat Indonesia, Tbk & BBRI & 11.675 & 3.640 & 3.660 & 4.400 \\
\hline 5 & PT Gudang Garam, Tbk & GGRM & 63.900 & 83.800 & 83.625 & 52.825 \\
\hline 6 & PT H.M. Sampoerna & HMSP & 3.830 & 4.730 & 3.710 & 2.120 \\
\hline 7 & PT Indocement Tunggal Prakasa, Tbk & INTP & 15.400 & 21.950 & 18.450 & 19.350 \\
\hline 8 & PT Indofood CBP Sukses Makmur, Tbk & ICBP & 8.575 & 8.900 & 10.450 & 11.225 \\
\hline 9 & PT Indofood Sukses Makmur, Tbk & INDF & 7.925 & 7.625 & 7.450 & 7.900 \\
\hline 10 & PT Jasa Marga, Tbk & JSMR & 4.320 & 6.400 & 4.280 & 5.200 \\
\hline 11 & PT Kalbe Farma, Tbk & KLBF & 1.515 & 1.690 & 1.520 & 1.610 \\
\hline 12 & PT Matahari Department Store, Tbk & LPPF & 15.125 & 10.000 & 5.600 & 4.220 \\
\hline 13 & PT PP (Persero), Tbk & PTPP & 3.810 & 2.640 & 1.805 & 1.590 \\
\hline 14 & PT Semen Indonesia, Tbk & SMGR & 9.175 & 9.900 & 11.500 & 11.900 \\
\hline 15 & PT Surya Citra Media, Tbk & SCMA & 2.800 & 2.480 & 1.870 & 1.420 \\
\hline 16 & PT Telekomunikasi Indonesia, Tbk & TLKM & 3.980 & 4.440 & 3.750 & 4.010 \\
\hline 17 & PT Unilever Indonesia, Tbk & UNVR & 38.800 & 55.900 & 45.400 & 42.150 \\
\hline 18 & PT United Tractors, Tbk & UNTR & 21.250 & 35.400 & 27.350 & 21.200 \\
\hline
\end{tabular}




\section{Gambar 1 : Grafik Perubahan Harga Saham}

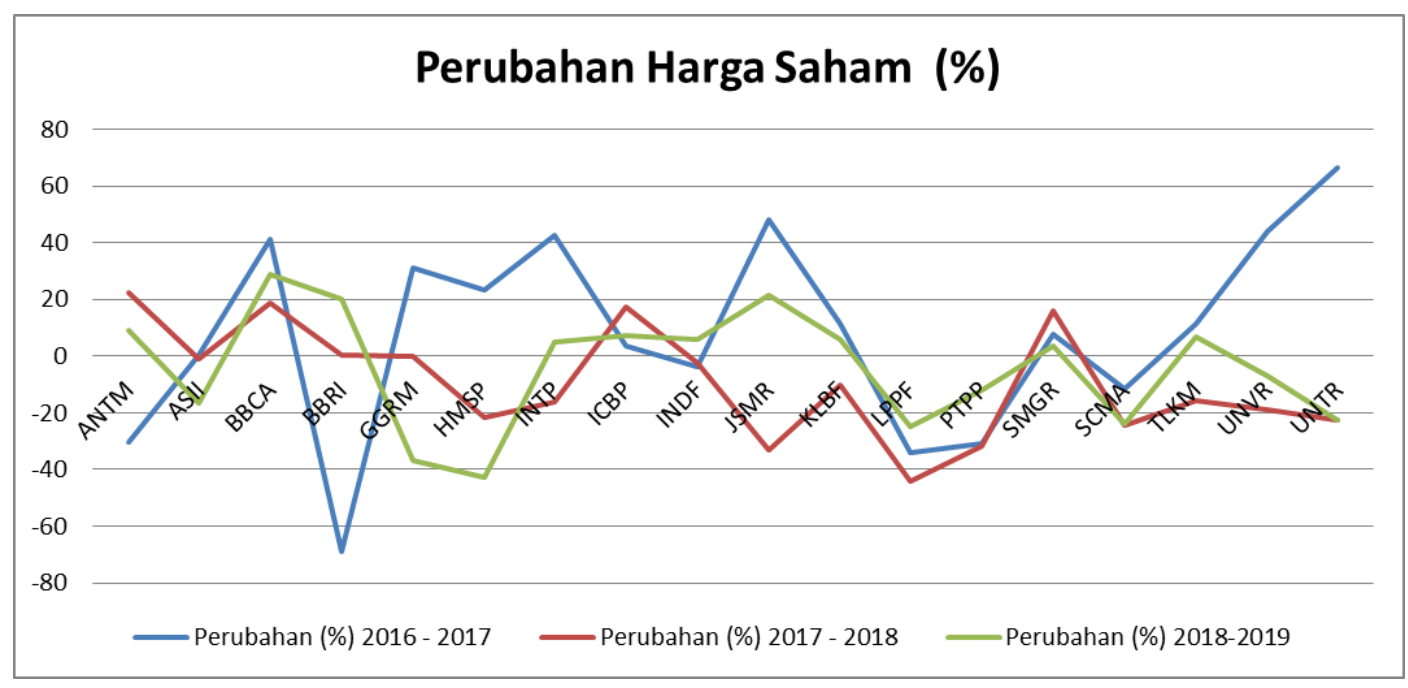

Sumber : Laporan Tahunan (Annual Report) dari www.idx.co.id, data diolah.

Dari tabel dan gambar di atas, umumnya perusahaan mengalami kenaikan atau penurunan harga saham setiap tahunnya dengan pergerakan saham yang fluktuatif inilah yang menarik bagi investor berkaitan dengan keuntungan. Fluktuasi harga saham dipengaruhi oleh banyak faktor internal maupun eksternal. Investor dapat memperoleh informasi mengenai kinerja perusahaan melalui laporan keuangannya dengan cara melakukan analisa dengan berbagai rasio. Analisa laporan keuangan bertujuan untuk memberikan informasi secara akurat mengenai kondisi suatu perusahaan. Dalam penelitian ini, rasio yg dipakai sebagai tolak ukur meneliti harga saham mencakup rasio arus kas operasi, keuntungan bersih, ukuran perusahaan dan nilai buku saham.

\section{Perumusan Masalah}

Perumusan masalah dalam penelitian antara lain :

1. Apakah arus kas operasi berpengaruh terhadap harga saham ?

2. Apakah laba bersih berpengaruh terhadap harga saham ?

3. Apakah ukuran perusahaan berpengaruh terhadap harga saham ?

4. Apakah price book value berpengaruh terhadap harga saham ?

\section{Tujuan Penelitian}

Untuk mengetahui pengaruh arus kas operasi, laba bersih, ukuran perusahaan dan price book value baik parsial maupun simultan terhadap harga saham pada perusahaan indeks LQ45 yang terdaftar di Bursa Efek Indonesia periode tahun 2016-2019.

\section{REVIU LITERATUR DAN HIPOTESIS}

\section{Arus Kas Operasi}

Aktivitas operasi yaitu aktivitas yang berkaitan dengan upaya perusahaan untuk menghasilkan produk sekaligus semua upaya yang terkait dengan menjual produk tersebut. Artinya, semua aktivitas yang berkaitan dengan upaya untuk memperoleh laba usaha dimasukkan dalam kelompok ini.

Menurut Hery (2016:88), aktivitas operasi meliputi transaksi-transaksi yang tergolong sebagai penentu besarnya laba atau rugi bersih. Penerimaan kas dari penjualan barang atau pemberian 
jasa merupakan sumber arus kas masuk yang utama. Penerimaan kas lainnya bersumber dari menurut pendapatan bunga, dividen \& penjualan sekuritas yg diperdagangkan. Sedangkan arus kas keluar mencakup pembelian barang dagangan, membayar tenaga kerja atau upah, pajak, bunga, beban utilitas, sewa, dan penarikan sekuritas yang diperdagangkan.

Berdasarkan beberapa pengertian di atas dapat disimpulkan bahwa aktivitas operasi merupakan aktivitas utama penghasil pendapatan bagi suatu entitas. Jumlah arus kas yang dihasilkan dari aktivitas operasi menjadi indikator utama untuk menentukan apakah operasi perusahaan dapat menghasilkan arus kas yang cukup untuk melunasi pinjaman, memelihara kemampuan operasi entitas, membayar deviden, dan melakukan investasi baru tanpa mengandalkan sumber dari luar. Perubahan arus kas dari aktivitas operasi akan memberikan sinyal positif kepada investor, yang menjadikan landasan investor untuk melakukan penjualan atau pembelian saham pada suatu perusahaan.

Arus kas operasi diperoleh dengan membagi jumlah arus kas operasi dengan kewajiban lancer, dimana perusahaan yang memiliki arus kas operasi terhadap kewajiban lancar dibawah 1 , berarti perusahaan tersebut tidak mampu melunasi kewajiban lancarnya hanya dengan menggunakan arus kas operasi saja.

AKO $=\frac{\text { Jumlah Arus Kas Operasi }}{\text { Kewajiban Lancar }}$

\section{Laba Bersih}

Dalam prinsip analisa keuangan fundamental, salah satu komponen laporan keuangan perusahaan yang perlu diperhatikan yaitu laba bersih. Hal ini dikarenakan keuntungan bersih tersebut adalah suatu ukuran yang mampu menggambarkan kinerja suatu perusahaan. Menurut Hery (2016:43), keuntungan bersumber dari pendapatan, beban, laba dan kerugian. Laba sebelum pajak penghasilan dikurangkan dengan pajak penghasilan akan diperoleh laba atau rugi bersih. Laba atau rugi bersih ini memberikan informasi bagi pengguna laporan keuangan sebuah ukuran ringkasan kinerja perusahaan secara keseluruhan selama periode berjalan. Menurut Kasmir (2018:303), laba bersih merupakan laba yang telah dikurangi biaya-biaya yang merupakan beban perusahaan dalam suatu periode tertentu, termasuk pajak.

Berdasarkan beberapa pengertian di atas dapat disimpulkan bahwa laba bersih merupakan laba yang dihasilkan perusahaan setelah dikurangi biaya termasuk biaya pajak. Pengukuran laba bersih menggunakan rumussebagai berikut :

\section{Laba Bersih = Ln Earning After Tax}

\section{Ukuran Perusahaan}

Ukuran perusahaan adalah suatu skala untuk mengklasifikasikan besar kecilnya perusahaan menurut berbagai cara, antara lain berdasarkan total aset, total penjualan, nilai pasar saham, dan sebagainya (Hery, 2017:3). Salah satu tolak ukur yang digunakan investor untuk pertimbangan menanamkan modal yaitu ukuran perusahaan, dikarenakan ukuran perusahaan memberik kemudahan perusahaan memperoleh dana dari pasar modal. Kemudahan ini sebagai sebuah kabar yg baik bagi para investor karena bisa merefleksikan nilai perusahaan dimasa depan.

Menurut Undang-Undang Republik Indonesia Nomor 20 Tahun 2008 Pasal 1 Tentang Usaha Mikro, Kecil, dan Menengah, klasifikasi ukuran perusahaan dibedakan menjadi usaha mikro, kecil dan menengah serta usaha besar. Usaha besar adalah usaha ekonomi produktif yang dilakukan oleh badan usaha dengan jumlah kekayaan bersih atau hasil penjualan tahunan lebih 
besar dari usaha menengah, yang meliputi usaha nasional milik negara atau swasta, usaha patungan, dan usaha asing yang melakukan kegiatan ekonomi di Indonesia.

Dalam penelitian ini rumus atau perhitungan Ukuran Perusahaan yang digunakan yaitu :

$$
\text { Size }=\text { Ln Total Aset }
$$

\section{Price to Book Value (PBV)}

Price to book value ratio (PBV) adalah rasio yang menunjukkan seberapa tinggi nilai pasar saham suatu perusahaan. Rasio harga pasar saham terhadap nilai bukunya menyampaikan pandangan investor tentang perusahaan. Dengan rasio PBV, investor dapat mengetahui langsung sudah berapa kali market value suatu saham dihargai dari book valuenya. Rasio PBV ini juga bisa menjadi sinyal positif bagi investor, dimana nilai rasio yang besar mencerminkan kesediaan pasar untuk menjual atau membeli saham dengan harga tinggi karena pasar percaya bahwa perusahaan memiliki prospek yang baik. Semakin tinggi rasio harga terhadap nilai buku, semakin besar kepercayaan pasar terhadap prospek perusahaan dan semakin banyak investor yang tertarik untuk membeli saham yang mengakibatkan kenaikan harga saham. Penelitian ini menggunakan rumus atau perhitungan:

Price to Book Value (PBV) $=\frac{\text { Harga Per Lembar Saham }}{\text { Nilai Buku Per Lembar Saham }}$

\section{Harga Saham}

Harga saham merupakan harga yang terbentuk di pasar saham yang besarannya dipengaruhi oleh hukum permintaan dan penawaran (Samsul, 2016:197). Investor akan tertarik membeli saham ketika harga saham turun, dan investor akan menjual sahamnya ketika harga saham naik. Dengan demikian harga saham dapat digunakan sebagai tolak ukur untuk mengetahui seberapa jauh manajemen dapat mengelola perusahaannya. Kekuatan permintaan dan penawaran saham sangat mempengaruhi harga saham di Bursa Efek Indonesia. Ketika perusahaan mencatatkan prestasi baik dalam menghasilkan keuntungan, akan semakin menaikkan permintaan saham dan akan disertai harga saham akan mengalami peningkatan. Akan tetapi, apabila perusahaan mencatatkan prestasi buruk, maka akan menurunkan permintaan saham yg mengakibatkan penurunan harga saham

Berdasarkan pengertian di atas dapat disimpulkan bahwa harga saham merupakan harga yang terjadi di pasar bursa pada waktu tertentu yang dipengaruhi oleh kekuatan permintaan dan penawaran.

Indikator harga saham dalam penelitian ini, menggunakan indikator harga saham penutupan (closing price), yaitu harga penutupan saham atau harga saham pada tutup tahun dari masing-masing perusahaan yang dapat dianggap dapat mewakili fluktuasi harga saham selama satu periode, yaitu :

\section{Ln Harga Saham Penutupan}

Faktor-faktor lainnya yang mempengaruhi naik turunnya harga saham antara lain faktor eksternal seperti : kondisi fundamental ekonomi makro, fluktuasi kurs rupiah terhadap mata uang asing, kebijakan pemerintah, manipulasi pasar. Selanjutnya faktor internal adalah : faktor fundamental perusahaan, aksi koorporasi perusahaan dan proyeksi kinerja perusahaan pada masa mendatang suatu perusahaan. 


\section{METODE PENELITIAN}

\section{Desain Penelitian}

Desain penelitian yg dilakukan merupakan penelitian kausal (causal research) yaitu penelitian untuk mengetahui pengaruh antara satu atau lebih variabel bebas terhadap variabel terikat. Variabel bebas dalam penelitian adalah arus kas operasi, laba bersih, ukuran perusahaan dan price book value, sedangkan variabel terikat adalah harga saham.

\section{Hipotesis}

Hipotesis merupakan pernyataan sementara atau dugaan yang paling memungkinkan yang masih harus dibuktikan melalui pengujian. Adapun hipotesis yang akan diuji adalah sebagai berikut :

$\mathrm{H}_{\mathrm{o} 1}$ : Arus kas operasi tidak berpengaruh terhadap harga saham

$\mathrm{H}_{\mathrm{a} 1}$ : Arus kas operasi berpengaruh terhadap harga saham

$\mathrm{H}_{\mathrm{o} 2}$ : Laba bersih tidak berpengaruh terhadap harga saham

$\mathrm{H}_{\mathrm{a} 2}$ : Laba bersih berpengaruh terhadap harga saham

$\mathrm{H}_{03}$ : Ukuran perusahaan tidak berpengaruh terhadap harga saham

$\mathrm{H}_{\mathrm{a} 3}$ : Ukuran perusahaan berpengaruh terhadap harga saham

$\mathrm{H}_{\mathrm{o} 4}$ : Price book value tidak berpengaruh terhadap harga saham

$\mathrm{H}_{\mathrm{a} 4}$ : Price book value berpengaruh terhadap harga saham

$\mathrm{H}_{05}$ : Arus kas operasi, laba bersih, ukuran perusahaan dan Price book value secara bersamasama tidak berpengaruh terhadap harga saham

$\mathrm{H}_{\mathrm{a} 5}$ : Arus kas operasi, laba bersih, ukuran perusahaan dan Price book value secara bersamasama berpengaruh terhadap harga saham

\section{Populasi dan Sampel}

Populasi yang digunakan dalam penelitian ini adalah perusahaan indeks LQ45 yang terdaftar di Bursa Efek Indonesia (BEI) periode tahun 2016-2019 dan selanjutnya sampel dalam penelitian menggunakan purposive sampling dengan kriteria :

1. Perusahaan indeks LQ45 yang terdaftar di Bursa Efek Indonesia dan sudah diaudit KAP

2. Perusahaan indeks LQ45 yang telah konsisten mempublikasikan laporan keuangan selama periode penelitian

3. Perusahaan indeks LQ45 yang menyajikan laporan keuangan menggunakan mata uang rupiah

4. Perusahaan indeks LQ45 dengan kondisi laba selama periode penelitian

5. Perusahaan indeks LQ45 dengan arus kas operasi positif selama periode penelitian

\section{Jenis Data}

Jenis data yang digunakan dalam penelitian ini adalah data sekunder, yaitu data yang yang tersaji pada laporan keuangan perusahaan indeks LQ45 yang terdaftar di Bursa Efek Indonesia periode tahun 2016-2019.

\section{HASIL DAN PEMBAHASAN}

Deskripsi Data Penelitian

Data penelitian adalah perusahaan indeks LQ45 yang terdaftar di Bursa Efek Indonesia periode tahun 2016-2019 yang terdiri dari 45 emiten dengan likuiditas tinggi, yang diseleksi melalui beberapa kriteria dari laporan keuangan diambil dari periode tahun 2016-2019 sebanyak 45 perusahaan.

Dalam penelitian ini, untuk menentukan jumlah sampel yang digunakan, peneliti menggunakan metode purposive sampling yang berarti sampel yang diambil adalah sampel yang memenuhi 
beberapa kriteria yang sudah ditetapkan sebelumnya sebanyak 18 perushaan setiap tahunnya, sehingga sampel dalam penelitian dalam 4 tahun pengamatan sebanyak 72 perusahaan.

\section{Analisis Statistik Deskriptif}

Analisa statistik deskriptif untuk memberikan gambaran tentang data yang digunakan dalam penelitian, terlebih dahulu ditinjau mengenai deskripsi variabel penelitian dengan analisis statistik deskriptif. Statistik deskriptif dapat dilihat dari nilai ratarata (mean), maksimal dan minimum. Adapun data yang akan dideskripsikan adalah data dari variabel-variabel yang diteliti yaitu Arus Kas Operasi (AKO), Laba Bersih (EAT), Ukuran Perusahaan (SIZE), Nilai Buku Saham (PBV), dan Harga Saham (Closing Price).

Hasil yang diperoleh dapat dijelaskan sebagai berikut :

1. Jumlah sampel (N) dalam penelitian ini berjumlah 72 sampel

2. Nilai rata-rata variabel AKO selama periode penelitian (2016-2019) yaitu 0,6171. Kisaran nilai variabel AKO ada pada nilai minimum 0,01 sampai dengan nilai maksimum 2,37. Dan nilai standar deviasi sebesar 0,55202 .

3. Nilai rata-rata variabel Earning After Tax (EAT) selama periode penelitian (2016-2019) yaitu 29,1825. Kisaran nilai variabel EAT ada pada nilai minimum 24,89 sampai dengan nilai maksimum 31,17. Dan nilai standar deviasi sebesar 1,33825.

4. Nilai rata-rata variabel SIZE selama periode penelitian (2016-2019) yaitu 31,7039. Kisaran nilai variabel SIZE ada pada nilai minimum 28,53 sampai dengan nilai maksimum 34,89. Dan nilai standar deviasi sebesar 1,47362.

5. Nilai rata-rata variabel $P B V$ selama periode penelitian (2016-2019) yaitu 7,4325. Kisaran nilai variabel PBV ada pada nilai minimum 0,57 sampai dengan nilai maksimum 85,18 . Dan nilai standar deviasi sebesar 14,71131.

6. Nilai rata-rata variabel Harga Saham selama periode penelitian (2016-2019) yaitu 8,8969. Kisaran nilai variabel Harga Saham ada pada nilai minimum 6,44 sampai dengan nilai maksimum 11,34. Dan nilai standar deviasi sebesar 1,18515.

\section{Hasil Uji Asumsi Klasik \\ Uji Normalitas}

Uji normalitas data untuk menguji apakah pada contoh regresi, variabel terikat \& variabel bebas keduanya memiliki distribusi normal atau tidak. Model regresi yg baik merupakan mempunyai distribusi normal \& atau mendekati normal. Uji normalitas dilakukan dengan menggunakan Uji Kolmogorov-Smirnov histogram normal P - Plot, dengan hasil sebagai berikut :

\section{Hasil Uji Kolmogrov - Smirnov}

One-Sample Kolmogorov-Smirnov Test

\begin{tabular}{llr} 
& & \multicolumn{1}{c}{$\begin{array}{c}\text { Unstandardized } \\
\text { Residual }\end{array}$} \\
\hline $\mathrm{N}$ & \multicolumn{1}{c}{ Mean } \\
\cline { 2 - 3 } Normal Parameters $^{\mathrm{a}, \mathrm{b}}$ & Std. Deviation & .0000000 \\
\hline Most Extreme Differences & Absolute & .89483542 \\
\cline { 2 - 3 } & Positive & .069 \\
\cline { 2 - 3 } & Negatif & .069 \\
\hline Test Statistic & & .051 \\
\hline
\end{tabular}




\begin{tabular}{l}
\hline Asymp. Sig. (2-tailed) \\
\hline a. Test distribution is Normal. \\
b. Calculated from data. \\
c. Lilliefors Significance Correction. \\
d. This is a lower bound of the true significance.
\end{tabular}

Berdasarkan tabel di atas, pengujian normalitas residual berdistribusi normal dengan ditunjukkan pada pengujian One - Sample Kolmogrov Smirnov dengan angka Asymp. Sig. (2tailed) sebesar 0,200 lebih besar dari 0,05, sehingga data penelitian sudah terdistribusi normal.

Selanjutnya hasil uji normalitas dengan grafik hasil uji grafik P-Plot menunjukkan bahwa model regresi layak dipakai dalam penelitian ini karena pada grafik normal plot terlihat titik-titik menyebar di sekitar garis diagonal serta penyebarannya mengikuti arah garis diagonal dan data yang dimiliki terlihat merata dan cukup baik yang berarti model regresi tersebut memenuhi asumsi normalitas yang berarti bahwa data terdistribusi secara normal.

\section{Uji Multikolinieritas}

Uji multikolinieritas untuk menguji apakah contoh regresi ditemukan adanya interaksi antara variabel bebas. Model regresi yg baik seharusnya tidak terjadi hubungan diantara variabel independen. Pengujian multikolinieritas pada penelitian ini menggunakan cara meregresikan model analisis dan melakukan uji hubungan antar variabel independen menggunakan memakai Tolerance dan Variance Inflation Factors (VIF). Agar tidak terjadi korelasi maka nilai yang harus dipenuhi yaitu nilai tolerance $>0,10$ dan $\mathrm{VIF}<10$.

Hasil Uji Multikolonieritas, nilai tolerance dari AKO adalah 0,569, EAT adalah 0,287, SIZE adalah 0,210, dan PBV adalah 0,646 yang mana hasil nilai tolerance di atas 0,10 . Hal ini berarti tidak ada kolerasi antar variabel bebas. Hasil perhitungan VIF dari AKO adalah 1,756, EAT adalah 3,485, SIZE adalah 4,754, dan PBV adalah 1,547 yang mana hasil nilai VIF dibawah 10. Hal ini berarti tidak ada kolerasi antar variabel bebas.

\section{Uji Heteroskedastisitas}

Untuk menguji apakah dalam model regresi terjadi ketidaksamaan varian dari residual dari satu pengamatan ke pengamatan lain. Untuk mengetahui ada atau tidaknya heteroskedastisitas dalam model regresi dapat dilihat pada grafik Scaterplot. Jika titik-titik dalam grafik menyebar tidak membentuk pola tertentu, maka tidak terjadi heteroskedastisitas.

Hasil pengujian heteroskedastisitas tidak ada atau tidak membentuk pola yang jelas, dimana titik-titik menyebar diatas dan dibawah angka 0 pada sumbu Y, maka ini menunjukkan bahwa tidak terjadi heteroskedastisitas pada model regresi, sehingga model regresi layak digunakan.

\section{Uji Autokorelasi}

Uji Autokorelasi digunakan untuk mengetahui ada atau tidaknya penyimpangan asumsi klasik autokorelasi, yaitu korelasi yang terjadi antara residual pada suatu periode pengamatan sebelumnya. Uji autokorelasi merupakan uji untuk melihat apakah terjadi korelasi antara suatu periode dengan periode sebelumnya. Pengujian ada tidaknya autokorelasi dalam penelitian ini menggunakan Uji Durbin Watson.

Hasil uji autokorelasi diperoleh nilai Durbin-Watson 0,767 dapat disimpulkan bahwa model regresi linier berganda berada diantara -2 sampai +2 maka dari hasil data tersebut tidak ada autokorelasi atau bebas autokorelasi. 


\section{Uji Regresi Linier Berganda}

Analisa regresi linier berganda bertujuan untuk mengetahui gambaran mengenai besarnya pengaruh antara dua atau lebih variabel $X$ sebagai variabel independen dengan variabel Y sebagai variabel dependen. Analisis linier berganda dapat dirumuskan sebagai berikut :

$$
\mathrm{Y}=\alpha+\beta 1 \mathrm{x} 1+\beta 2 \mathrm{x} 2+\beta 3 \mathrm{x} 3+\beta 4 \mathrm{x} 4+\mathrm{e}
$$

Hasil Uji Regresi Linier Berganda, diperoleh nilai Coefficients sehingga dapat disusun persamaan regresi linier berganda seperti di bawah ini :

$$
\mathrm{Y}=2,901-1,037 \times 1+0,734 \times 2-0,470 \times 3+0,014 \times 4+\mathrm{e}
$$

\section{Hasil Uji Hipotesis \\ Uji t (Parsial)}

Hasil penghitungan dari nilai thitung dan tarif signifikannya yang dapat sebagai berikut:

\begin{tabular}{|c|c|c|c|c|c|c|}
\hline \multirow[b]{4}{*}{ Model } & \multicolumn{6}{|c|}{ Coefficients $^{\mathbf{a}}$} \\
\hline & & \multirow{2}{*}{\multicolumn{2}{|c|}{ Unstandardized Coefficients }} & \multirow{3}{*}{$\begin{array}{l}\text { Standardized } \\
\text { Coefficients } \\
\text { Beta }\end{array}$} & \multirow[b]{3}{*}{$\mathrm{t}$} & \multirow[b]{3}{*}{ Sig. } \\
\hline & & & & & & \\
\hline & & $\mathrm{B}$ & Std. Error & & & \\
\hline \multirow[t]{5}{*}{1} & (Constant) & 2.901 & 2.836 & & 1.023 & .310 \\
\hline & $\mathrm{AKO}$ & -1.037 & .262 & -.483 & -3.952 & .000 \\
\hline & EAT & .734 & .153 & .829 & 4.816 & .000 \\
\hline & SIZE & -.470 & .162 & -.584 & -2.906 & .005 \\
\hline & PBV & .014 & .009 & .177 & 1.545 & .127 \\
\hline
\end{tabular}

\section{Hasil Uji t}

a. Dependent Variable: LN HARGA SAHAM

Berdasarkan hasil uji statistik di atas, diketahui masing-masing variabel independen terhadap variabel dependen dapat dijelaskan sebagai berikut :

1. Variabel AKO mempunyai nilai thitung 3,952 lebih besar dari nilai tabel 1,99601 dan nilai signifikansi sebesar 0,000 lebih kecil dari 0,05 sehingga $\mathrm{H}_{01}$ ditolak, artinya secara parsial AKO berpengaruh negatif dan signifikan terhadap harga saham.

2. Variabel EAT mempunyai nilai $t_{\text {hitung }} 4,816$ lebih besar dari nilai $t_{\text {tabel }} 1,99601$ dan nilai signifikansi sebesar 0,000 lebih kecil dari 0,05 sehingga $\mathrm{H}_{\mathrm{o} 2}$ ditolak, artinya secara parsial EAT berpengaruh positif dan signifikan terhadap harga saham.

3. Variabel SIZE mempunyai nilai thitung 2,906 lebih besar dari nilai $t_{\text {tabel }} 1,99601$ dan nilai signifikansi sebesar 0,005 lebih kecil dari 0,05 sehingga $\mathrm{H}_{03}$ ditolak, artinya secara parsial SIZE berpengaruh negatif dan signifikan terhadap harga saham.

4. Variabel PBV mempunyai nilai thitung 1,545 lebih kecil dari nilai tabel 1,99601 dan nilai signifikansi sebesar 0,127 lebih besar dari 0,05 sehingga $\mathrm{H}_{\mathrm{o} 4}$ diterima, artinya secara parsial PBV tidak berpengaruh terhadap harga saham.

\section{Uji f (Simultan)}

Uji f dilakukan untuk mengetahui apakah variabel independen (variabel bebas) secara simultan atau bersama-sama memiliki pengaruh terhadap variabel dependen (variabel terikat). Menentukan tingkat signifikan $(\infty)$, yaitu sebesar $5 \%(0,05)$ dapat dilakukan dengan berdasarkan nilai probabilitas dengan cara pengambilan keputusan adalah :

1. Jika nilai probabilitas $>0,05$, maka $\mathrm{H}_{\mathrm{o}}$ diterima $\mathrm{H}_{\mathrm{a}}$ ditolak.

2. Jika nilai probabilitas $<0,05$, maka $\mathrm{H}_{\mathrm{o}}$ ditolak $\mathrm{H}_{\mathrm{a}}$ diterima. 
Hasil pengujian yang dilakukan dapat dilihat pada tabel ANOVA berikut ini, dimana nilai f hitung dan taraf signifikasinya sebagai berikut :

\section{Hasil Uji f}

\begin{tabular}{|c|c|c|c|c|c|c|}
\hline \multicolumn{7}{|c|}{$\mathbf{A N O V A}^{\mathrm{a}}$} \\
\hline Model & & Sum of Squares & Df & Mean Square & $\mathrm{F}$ & Sig. \\
\hline \multirow[t]{3}{*}{1} & Regression & 42.874 & 4 & 10.719 & 12.632 & $.000^{\mathrm{b}}$ \\
\hline & Residual & 56.852 & 67 & .849 & & \\
\hline & Total & 99.726 & 71 & & & \\
\hline
\end{tabular}

a. Dependent Variable: LN HARGA SAHAM

b. Predictors: (Constant), PBV, EAT, AKO, SIZE

Hasil uji ANOVA atau pengujian simultan menunjukkan bahwa nilai signifikasi yang diperoleh adalah 0,000. Karena nilai siginifikasi lebih kecil dari 0,05 maka $\mathrm{H}_{\mathrm{a} 5}$ diterima dan $\mathrm{H}_{05}$ ditolak, yang mempunyai arti bahwa variabel AKO, EAT, SIZE dan PBV secara simultan berpengaruh terhadap harga saham pada perusahaan indeks LQ45 yang terdaftar di Bursa Efek Indonesia 2016-2019.

\section{Uji Koefisien Determinasi $\left(\mathbf{R}^{\mathbf{2}}\right)$}

Uji koefisien determinasi $\left(\mathrm{R}^{2}\right)$ bertujuan untuk mengetahui pengaruh dari variabel bebas atau variabel independen $(\mathrm{X})$ terhadap variabel dependen $(\mathrm{Y})$, atau dengan kata lain nilai koefisien determinasi atau $\mathrm{R}^{2}$ untuk memprediksi dan melihat seberapa besar kontribusi pengaruh yang diberikan variabel $\mathrm{X}$ secara simultan terhadap variabel $\mathrm{Y}$ denan Kriteria pengujian yaitu jika nilai adjusted $\mathrm{R}^{2}$ negatif, maka nilai adjusted $\mathrm{R}^{2}$ dianggap bernilai nol.

Besarnya pengaruh variabel bebas secara simultan berpengaruh terhadap variabel terikat sebagai berikut :

\section{Uji Koefisien Determinasi $\mathbf{R}^{2}$}

\begin{tabular}{|c|c|c|c|c|c|}
\hline \multirow[b]{2}{*}{ Model } & \multicolumn{4}{|c|}{ Model Summary } & \multirow[b]{2}{*}{ Durbin-Watson } \\
\hline & $\mathrm{R}$ & R Square & $\begin{array}{c}\text { Adjusted R } \\
\text { Square } \\
\end{array}$ & $\begin{array}{c}\text { Std. Error of the } \\
\text { Estimate }\end{array}$ & \\
\hline 1 & $.656^{\mathrm{a}}$ & .430 & .396 & ,92116 & .767 \\
\hline
\end{tabular}

a. Predictors: (Constant), PBV, EAT, AKO, SIZE

b. Dependent Variable: LN HARGA SAHAM

Berdasarkan di atas, nilai adjudted $\mathrm{R}^{2}$ sebesar 0,396 berarti sekitar 39,6 \% ini menunjukkan bukti bahwa kontribusi pengaruh dari variabel AKO, EAT, SIZE dan PBV. Sedangkan sisanya $60,4 \%$ dijelaskan atau dipengaruhi oleh faktor-faktor lain yang dapat mempengaruhi harga saham.

\section{HASIL DAN PEMBAHASAN}

\section{Pengaruh Arus Kas Operasi Terhadap Harga Saham}

AKO berpengaruh negatif terhadap harga saham, dikarenakan adanya saldo kas yang menganggur dalam jumlah besar, sebagai akibat dari manajemen yang kurang efektif dalam mengelola kas operasional perusahaan. Oleh sebab itu, laba yang dihasilkan dari aktivitas 
operasi perusahaan menjadi tidak maksimal. Karena hal tersebut, menjadi kurang menarik bagi investor untuk berinvestasi yang mengakibatkan menurunnya harga saham.

\section{Pengaruh Laba Bersih Terhadap Harga Saham}

Adanya pengaruh yang signifikan antara Earning After Tax terhadap harga saham yang dapat diartikan semakin besar laba bersih yang dihasilkan oleh perusahaan, akan berpengaruh terhadap kenaikan harga saham di perusahaan indek LQ45 yang terdaftar di Bursa Efek Indonesia.

\section{Pengaruh Ukuran Perusahaan Terhadap Harga Saham}

SIZE berpengaruh negatif terhadap harga saham, Hal ini dapat terjadi karena investor percaya bahwa perusahaan dengan total aset yang besar cenderung menetapkan laba ditahan yang lebih tinggi daripada membayar dividen kepada investor. Tujuan dari laba ditahan tersebut adalah agar nantinya dapat digunakan kembali sebagai modal untuk melakukan aktivitas operasional perusahaan. Perusahaan yang lebih memilih laba ditahan daripada dividen dapat mempengaruhi harga saham sehingga investor tidak meliriknya. Hal ini dianggap wajar, karena tujuan utama investor untuk menginvestasikan dananya adalah mendapatkan dividen.

\section{Pengaruh Nilai Buku Saham Terhadap Harga Saham}

Hasil penelitian ini menunjukkan bahwa nilai buku suatu saham tidak berpengaruh terhadap harga saham, hal ini menunjukkan bahwa variabel PBV tidak dapat mempengaruhi keputusan investor dalam mengambil keputusan investasi. Hal tersebut bisa disebabkan karena variabel PBV yang menggunakan nilai buku saham sebagai indikator perhitungan nilainya bersifat tetap dan tidak berubah-ubah. Sedangkan harga saham dalam penelitian ini menggunakan indikator nilai pasar yang nilainya selalu berubah-ubah di pasar bursa.

\section{KESIMPULAN}

Pengaruh dari Arus Kas Operasi dengan indikator AKO, Laba Bersih dengan indikator Earning After Tax (EAT), Ukuran Perusahaan dengan indikator SIZE, dan Nilai Buku Saham dengan indikator Price to Book Value (PBV) secara parsial maupun secara simultan terhadap Harga Saham pada perusahaan indeks LQ45 yang terdaftar di Bursa Efek Indonesia tahun 20162019 diperoleh hasil, sebagai berikut :

1. Arus kas operasi berpengaruh negatip signifikan terhadap harga saham.

2. Laba bersih dengan menggunakan indikator Earning After Tax pengaruh positif signifikan terhadap harga saham.

3. Ukuran perusahaan dengan menggunakan indikator SIZE pengaruh negatif terhadap harga saham..

4. Nilai Buku Saham tidak pengaruh terhadap harga saham.

5. Secara simultan, arus kas operasi, laba bersih, ukuran perusahaan dan nilai buku saham berpengaruh signifikan terhadap harga saham.

6. Faktor variabel arus kas operasi, laba bersih, ukuran perusahaan, dan nilai buku saham dapat mempengruhi harga saham sebesar $39,6 \%$ sedangkan sisanya 60,4\% dijelaskan atau dipengaruhi oleh faktor-faktor lain.

\section{DAFTAR PUSTAKA}

Fahmi, Irham. 2020. Pengantar Manajemen Keuangan Teori dan Soal Jawab. Bandung : Alfabeta.

Ghozali, Imam dan Dwi Ratmono. 2016. Analisis Multivariat dengan Program IBM SPSS 23 (Edisi 8). Semarang : Badan Penerbit Universitas Diponegoro. 
Ghozali, Imam dan Dwi Ratmono. 2020. Analisis Multivariat dan Ekonometrika (Edisi 2). Semarang : Badan Penerbit Universitas Diponegoro.

Harahap, Sofyan Syafri. 2018. Analisis Kritis Laporan Keuangan. Jakarta : PT RajaGrafindo Persada.

Hartono, Jogiyanto. 2017. Teori Portofolio dan Analisis Investasi (Edisi Kesebelas). Yogyakarta : BPFE.

Hermuningsih, Sri. 2019. Pengantar Pasar Modal Indonesia Edisi 2. Yogyakarta : UPP STIM YKPN.

Hery. 2016. Analisis Laporan Keuangan. Jakarta : Grafindo.

Kasmir. 2018. Analisis Laporan Keuangan. Jakarta : RajaGrafindo Perkasa.

Miranti, Pan Budi Marwoto, dan Medinal. 2017. Pengaruh Laba Bersih dan Arus Kas terhadap Harga Saham pada Perusahaan Sektor Perbankan yang Terdaftar pada Indeks LQ 45 Bursa Efek Indonesia Periode 2011-2015. Jurnal Ilmiah Akuntansi Bisnis dan Keuangan, 9(2), 31-43.

Putri, Ayu Utami Sutisna, Willy Sri Yuliandhari, dan Vaya Juliana Dillak. 2017. Pengaruh Laba Bersih dan Arus Kas terhadap Harga Saham (Studi Empiris pada Perusahaan LQ 45 yang Terdaftar di Bursa Efek Indonesia Periode 2011-2015. e-Proceeding og Management, 4(3), 2605-2612.

Republik Indonesia. 1995. Undang-Undang Republik Indonesia Nomor 8 Tahun 1995 tentang Pasar Modal. Jakarta.

Republik Indonesia. 2008. Undang-Undang Republik Indonesia Nomor 20 Tahun 2008 Pasal 1 dan 6 tentang Usaha Mikro Kecil, dan Menengah. Jakarta.

Samsul, Muhammad. 2016. Pasar Modal \& Manajemen Portofolio (Edisi Kedua). Jakarta : Erlangga.

Santoso, Singgih. 2014. Statistik Parametrik Konsep dan Aplikasi dengan SPSS. Jakarta : PT. Elex Media Komputindo.

Setiawati, Dewi. 2018. Pengaruh Laba Bersih dan Arus Kas Operasi terhadap Harga Saham pada Perusahaan Food and Beverages yang Terdaftar di Bursa Efek Indonesia Periode 2012-2015.Dinamika $\quad$ Ekonomi Jurnal Ekonomi dan Bisnis, 11(2), 319330.

Sidiqi, Barka. 2020. Informasi Laba dan Arus Kas terhadap Harga Saham Melalui Book Value (Studi Empiris pada Perusahaan yang Terdaftar di Jakarta Islamic Index Periode 20162018).

Sugiyono. 2019. Metode Penelitian Kuantitatif, Kualitatif dan $R \&$ D. Bandung : Alfabeta.

Wahyuningsih, Indah, Jeck Febriand Adel, dan Sri Ruwanti. 2017. Pengaruh Arus Kas Operasi, Laba Bersih, Ukuran Perusahaan dan Nilai Pasar Terhadap Harga Saham pada Perusahaan Manufaktur yang Terdaftar di Bursa Efek Indonesia 2013-2016. 